\title{
Winter ecology of the sea ice biota in Weddell Sea pack ice
}

\author{
David L. Garrison ${ }^{1}$, Ann R. Close ${ }^{2}$ \\ ${ }^{1}$ Institute of Marine Sciences, University of California, Santa Cruz, California 95064, USA \\ ${ }^{2}$ Bermuda Biological Station for Research, Inc., Ferry Reach GE01, Bermuda
}

\begin{abstract}
During winter 1988, we examined the ice community in the ice edge region of the Weddell and Scotia Seas. We measured chemical and physical characteristics of the ice habitat, chlorophyll a (chl a), particulate organic carbon and nitrogen (POC and PON) and ATP. We also analyzed the composition and biomass of the ice biota by microscopy. Air temperature during the study ranged from above freezing to as low as $-18^{\circ} \mathrm{C}$. Large fluctuations over a few days were common. Temperature at the ice surface generally followed air temperature, but with a short lag period. As a result of low temperatures at the ice surface, in situ salinity in the upper layer of ice floes reached $>100 \%$. Samples were taken from newly forming, young, first-year and older sea ice. Ice floes had variable amounts of snow cover. Floes were primarily comprised of congelation ice $(56 \%)$ but also contained significant amounts


as chlorophyll concentrations and integrated POC, PON and ATP generally increased with increasing ice age or thickness. High $\mathrm{C}: \mathrm{chl}$ a, C:N and C:ATP ratios characterized all ice types and suggested substantial detritus in the ice. The ice biota was comprised of bacteria, algae, protozoans and some metazoa. Microscopically estimated biomass in floes ranged from $<50$ to $>1000 \mathrm{mg} \mathrm{C} \mathrm{m}^{-2}$, with the highest values from older ice floes. Estimates of carbon calculated from ATP showed good agreement with estimates derived from microscopy. The high concentrations of living organisms and detritus in sea ice suggest the potential importance of the ice community to the pelagic system particularly during the winter. The source of unexpectedly high concentrations of detritus, at least in young sea ice, is uncertain. The winter ice assemblage did not differ markedly from the assemblages found during other seasons, and overall the seasonal biomass variation within the pack ice community appears to be low. Resting stages such as archaeomonads and dinoflagellate cysts were common in the ice, and cyst formation for the dinoflagellates appears to take place during the winter as well as in the late summer. Although earlier studies have emphasized the importance of harvesting and concentration of organisms from the water during episodes of frazil ice formation, we did not see evidence for this from our analysis of biomass associated with different structural types of ice. The initial physical concentration of organisms in ice, however, could be quickly obscured by subsequent in situ growth or grazing. Based on a favorable light and temperature regime in drifting pack ice at high latitudes, we speculate that production and community development is likely even during winter.
\end{abstract}

\section{INTRODUCTION}

Studies now indicate that large areas of the drifting pack ice surrounding Antarctica are colonized by microorganisms ranging from bacteria to metazoans (Ackley et al. 1979, Garrison et al. 1986, Kottmeier \& Sullivan 1990, Spindler et al. 1990 and reviewed by Garrison 1991). It has also become evident from recent studies that surface layer and internal assemblages usually predominate in the pack ice regions, whereas bottom layer and under-ice platelet layer assemblages are more characteristic of the nearshore, land-fast ice (Horner et al. 1988, Garrison \& Watanabe 1991 and references above). Although factors controlling community development in nearshore habitats are becoming well known (e.g. Grossi et al. 1987, Arrigo et al. 1991), considerably less is known about pack ice habitats (Garrison \& Buck 1991, Eicken 1992). It seems 
reasonable, however, to expect that factors controlling biological development in the pack ice habitats will differ somewhat from those in nearshore, land-fast ice (e.g. Garrison 1991, Garrison \& Buck 1991, Garrison \& Watanabe 1991).

The seasonal dynamics of the pack ice biota are still poorly understood. Initial incorporation of organisms is apparently often the result of the harvesting and concentration of particulate material from the water column during episodes of frazil ice formation (Garrison et al. 1983, 1989, Spindler \& Dieckmann 1986, Dieckmann et al. 1991). Although this mechanism appears to explain the occurrence of assemblages throughout ice floes in frazil-dominated pack ice, the fate of organisms incorporated in this manner and details about their survival and subsequent growth in ice, if any, is still largely unknown. A considerable amount of the seasonal sea ice is formed during the austral winter and, because of the harvesting of organisms by frazil ice, this may be the initial stage in establishing an ice biota in young pack ice. Moreover, some older drifting ice floes survive summer melting and may begin the winter season with well-established populations (e.g. Buck et al. 1989, Garrison \& Buck 1989). Thus, it may be essential to know the conditions for growth and survival in ice during the winter in order to understand the pattern of seasonal development in the following spring and summer (e.g. see Garrison \& Buck 1991). During winter the biota and accumulated detritus in sea ice may be an important resource for some pelagic consumers (e.g. Daly 1990, Daly \& Macaulay 1991, Garrison et al. 1992), but the composition and availability of this material has not been adequately quantified.

During the austral winter of 1988 , we sampled ice floes in the drifting pack ice of the Weddell/Scotia Sea regions. We made measurements of chlorophyll a (chl a), particulate carbon and nitrogen and ATP in ice to provide information about the community composition, biomass and metabolic state. In addition, microscopy studies of the biota in selected floes were made to provide more specific information about species present, their trophic mode and about possible lifecycle strategies for some ice-associated organisms. The discovery of active flagellates and ciliates throughout the ice, even at extremely low temperatures and high salinities, indicates survival and activity for these forms. The presence of resting stages for other organisms suggests that a variety of overwintering strategies may be used by other ice-associated organisms. This study, in conjunction with previous late spring and autumn observations (Garrison \& Buck 1989), comprises some of the first composite information on the seasonal dynamics of the biota of a pack ice community.

\section{MATERIALS AND METHODS}

Samples were collected from pack ice floes in the Weddell Sea as part of the AMERIEZ (Antarctic Marine Ecosystem Research at the Ice Edge Zone) austral winter cruise (Fig. 1). Ice samples were collected from throughout ice floes with a $7.6 \mathrm{~cm}$ diameter, CRREL (SIPRE) ice-coring auger. Before sampling, snow was removed to expose the underlying hard ice. Usually a short core (approximately $20 \mathrm{~cm}$ ) was removed from the surface layer of the floe and brine was allowed to accumulate in the void, then the brine was sampled using a large syringe. Following brine removal, the remainder of the ice core was collected. Ice cores were immediately sectioned into approximately $20 \mathrm{~cm}$ lengths and placed in individual plastic bottles. New ice (grease, pancake or nilas ice) was collected with a bucket or by using an ice saw and placed in plastic bottles. Samples were immediately stored in insulated containers to protect them from temperature change. Where replicate cores were required for analysis (e.g. for ice structure and population analysis), they were collected within a $1 \mathrm{~m}$ area.

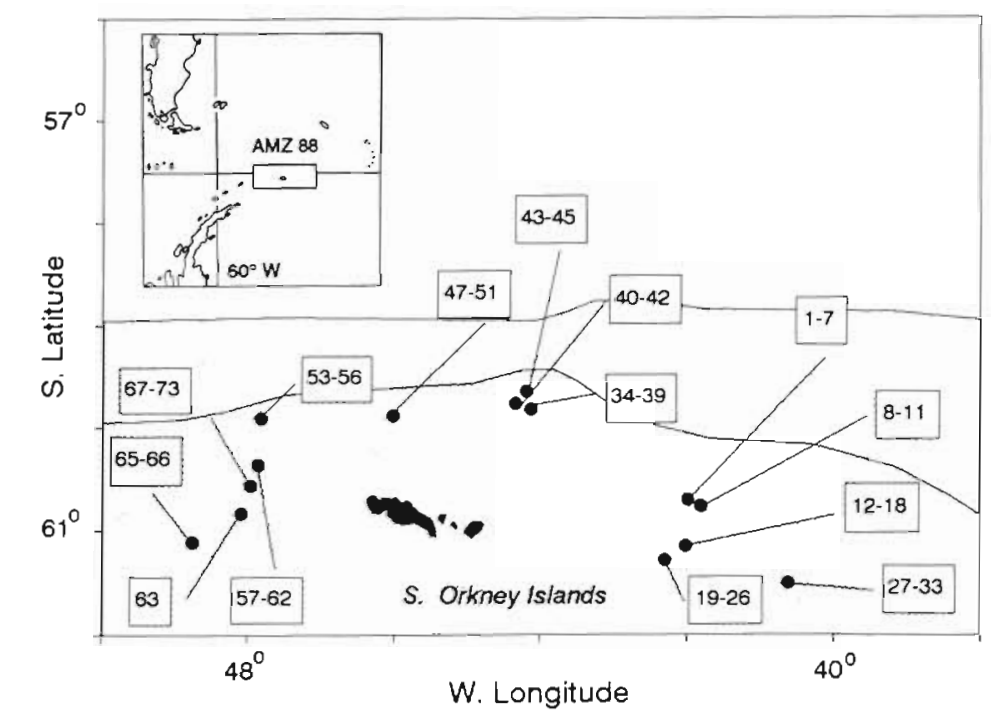

Fig. 1. Location of ice samples collected from 10 June to 2 July 1988 during Leg I of the Antarctic Marine Ecosystem Research at the Ice Edge Zone (AMERIEZ) winter cruise. Inset: location of study area. Range of sample numbers (e.g. 1-7) are replicate core samples collected at one location. Shaded area indicates ice cover: light shading is the approximate increase in sea ice cover from 1 to 30 June as incicated by satellite data and observations during the AMERIEZ cruise. The analyses are summarized in Table 1 
Ice core samples for biota analysis and some of our samples for measurements of particulate organic carbon and nitrogen (POC and PON) and ATP were melted in ca $1.0 \mathrm{l}$ of $0.2 \mu \mathrm{m}$ filtered surface seawater to buffer osmotic changes as samples melted; this procedure was not required for brine samples (Garrison \& Buck 1986). Filtered seawater and melted sample volume were carefully measured to correct concentrations to the original ice volume. Samples of newly forming sea ice were melted and processed without using the dilution procedure. These samples were not used for biota analysis.

Chemical characterization of biota. Aliquots (usually $150 \mathrm{ml}$ ) of brine or melted ice samples were filtered through whatman glass fiber filters $(\mathrm{GF} / \mathrm{F})$ and analyzed for chl a using the fluorescence technique outlined in Parsons et al. (1984). An additional $500 \mathrm{ml}$ was filtered through precombusted $\mathrm{GF} / \mathrm{F}$ filters for POC and PON analysis. After filtration, these samples were rinsed with dilute $\mathrm{HCl}$ and dried at $60^{\circ} \mathrm{C}$. Dried filters were stored in a desiccator and returned to our laboratory where they were analyzed on a PerkinElmer 240B Elemental Analyzer standardized with acetanilide. For ATP measurements, 150 to $250 \mathrm{ml}$ was filtered through GF/F filters. These filters were immediately transferred to $5 \mathrm{ml}$ of boiling phosphate buffer $(\mathrm{pH}=7.4)$ in vented Vacutainer tubes and extracted for $5 \mathrm{~min}$. These tubes were sealed and placed in a $-20^{\circ} \mathrm{C}$ freezer until analysis. ATP samples were analyzed using a Lab-Line ATP Photometer, Model 9140. The instrument was calibrated with an ATP standard disodium salt (Sigma) which was hydrated and mixed with equal volumes of $0.04 \mathrm{M} \mathrm{MgSO}_{4}$ and $0.1 \mathrm{M}$ arsenate buffer (Holm-Hansen \& Booth 1966, Close 1989).

Biota studies. Aliquots of the filtered seawaterdiluted samples and brine (125 or $250 \mathrm{ml})$ were preserved with acid Lugol's solution for microscopy analysis. Some replicate samples were preserved with Karnovsky's fixative (Gold 1976). Preserved samples were returned to our laboratory, aliquots of 2 to $50 \mathrm{ml}$ were settled for at least $48 \mathrm{~h}$ and organisms counted using an inverted microscope (our methods are described in Garrison \& Buck 1989). In addition, aboard the ship, aliquots of brine samples (10 to $50 \mathrm{ml}$ ) were concentrated on unstained $0.8 \mu \mathrm{m}$ Nuclepore filters with glutaraldehyde (approximately $2 \%$ final concentration) added to the filter funnel. The filters were mounted with Zeiss immersion oil and either counted aboard ship using an Olympus BH2 microscope using epifluorescence with blue light excitation, or frozen at $\mathrm{ca}-20^{\circ} \mathrm{C}$ and returned to our laboratory and counted using a Zeiss microscope with a 450 to $490 \mathrm{~nm}$ excitation filter, $510 \mathrm{~nm}$ dichroic mirror and $520 \mathrm{~nm}$ barrier filter (e.g. Booth 1987). All filters were examined within $6 \mathrm{mo}$ of collection. Abundance estimates for brine samples were usually lower than those obtained from diluted and melted ice samples, suggesting to us that many organisms remain within the ice matrix and that winter brine samples do not provide quantitative estimates of organisms occurring in the microhabitat of brine inclusions. However, these filter-concentrated brine samples examined by fluorescence microscopy should still provide accurate assessment of the relative abundance of autotrophic and heterotrophic forms among flagellates comprising the ice assemblage that could not be determined from our preserved and settled samples.

For both settled and filter-concentrated samples, we measured cell dimensions to calculate cell volumes and estimated cell carbon from published volume to carbon relationships (e.g. Beers \& Stewart 1970, Eppley et al. 1970, Putt \& Stoecker 1989). These methods are consistent with those used in previous studies and the potential biases of volume:carbon conversions are discussed in Garrison \& Buck (1989).

To estimate bacterial abundance and biomass, $2 \mathrm{ml}$ of either Karnovsky's-preserved samples or Lugol'spreserved samples cleared with $\mathrm{Na}_{2} \mathrm{~S}_{2} \mathrm{O}_{3}$ were concentrated on $0.2 \mu \mathrm{m}$ Nuclepore filters stained with 4',6-diamidino-2-phenylindole (DAPI) according to Coleman (1980). These filters were counted on a Leitz Fluorescence Microscope at $1250 \times$ using UV excitation. Size was determined from microphotographs (e.g. Lee \& Fuhrman 1987) and carbon volumes were con-

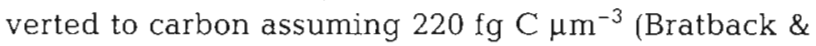
Dundas 1984, Kottmeier \& Sullivan 1987).

Ice structural and environmental conditions. Replicate cores or ice samples were collected for structural analysis of ice floes (Table 1). Thin vertical sections of ice samples were cut aboard ship, examined under crossed polarized filters and photographed (e.g. Lange 1988, Eicken \& Lange 1989 for methods). Core sections were characterized as being comprised of granular (frazil and infiltration ice), columnar (congelation ice) or of mixed ice types. The remainder of the structural core was melted and chlorophyll, POC and PON analyses were performed as previously described. Bulk salinity was measured with a refractometer. Dissolved inorganic nutrients were also measured, and the results have been reported in Garrison et al. (1990).

Air, snow surface, ice surface and brine temperatures were measured at the time of sampling. Measurements of snow cover and ice floe thickness and the position of the freeboard level of ice floes were also recorded as part of our field observations. Air temperatures were recorded aboard ship at approximately $3 \mathrm{~h}$ intervals. Sea surface temperature was collected as part of the hy. drographic sampling program (Muench et al. 1990). Photosynthetically available radiation (PAR) was continuously recorded aboard ship with a Biospherical Instruments Model QSR-240 (Lizotte \& Sullivan 1991). 
Table 1. Ice samples collected during AMERIEZ 88 showing replicate samples from individual ice floes. Range of numbers under 'Analysis' refers to core numbers as shown in Fig. 1. Typical floe thickness given in remarks

\begin{tabular}{|c|c|c|c|c|c|c|}
\hline \multirow[t]{2}{*}{ Floe } & \multicolumn{5}{|c|}{ Analysis } & \multirow[t]{2}{*}{ Remarks } \\
\hline & ChI a & $C: N$ & ATP & Biota & Structure & \\
\hline A & $1-5$ & $1,3,6$ & 1,3 & 1 & 2,4 & $\begin{array}{l}\text { Old ice, } 78 \mathrm{~cm} \text {, predominately congellation ice, } \\
\text { infiltration layer }\end{array}$ \\
\hline $\mathrm{B}$ & $8-11$ & $8-11$ & $8-11$ & & 9 & Young ice, $38 \mathrm{~cm}$, mixed structure \\
\hline $\mathrm{C}$ & $12-16$ & $12-14$ & $12-14$ & & 16 & Young ice, $40 \mathrm{~cm}$, predominately frazil ice in bands \\
\hline $\mathrm{D}$ & $\begin{array}{l}19-22 \\
25-26\end{array}$ & $19-22$ & $19-22$ & 19,21 & 20 & $\begin{array}{l}\text { Young ice, ca } 54 \mathrm{~cm} \text {, predominately frazil ice } \\
\text { with variable grain sizes }\end{array}$ \\
\hline F & $\begin{array}{l}30-33 \\
33 a, b\end{array}$ & $\begin{array}{l}30-33 \\
33 a, b\end{array}$ & $30-33$ & 30,32 & $33 a, b$ & Young ice, ca $40 \mathrm{~cm}$, mixed structure \\
\hline $\mathrm{H}$ & $40-42$ & $40-41$ & $40-41$ & 40 & 42 & $\begin{array}{l}\text { Old ice, } 130 \text { to } 149 \mathrm{~cm} \text {, predominately frazil ice, } \\
\text { apparent infiltration layer, apparent rafting }\end{array}$ \\
\hline I & $43-45$ & $43-44$ & $43-44$ & 44 & 45 & Young ice,ca $30 \mathrm{~cm}$, predominately frazil ice \\
\hline $\mathrm{K}$ & $53-54$ & 53 & 53 & & & Old ice, 104 to $110 \mathrm{~cm}$ \\
\hline $\mathrm{L}$ & $61-62$ & 61 & & & 62 & Old ice, $11 \mathrm{~cm}$, predominately congelation ice \\
\hline M & 53 & 63 & & & 63 & Young ice, $80 \mathrm{~cm}$, predominately frazil ice, rafted floe \\
\hline$N$ & $65-66$ & 65 & & & 66 & $\begin{array}{l}\text { Old ice, } 121 \mathrm{~cm} \text {, mixed ice types, infiltration layer } \\
\text { present }\end{array}$ \\
\hline
\end{tabular}

\section{RESULTS}

\section{Environmental regime of ice edge zone}

The study was conducted at an advancing ice edge of the Weddell/Scotia Sea region (see Fig. 1). Satellitederived ice cover charts showed that from 1 to 30 June the ice edge moved northward from ca $60.5-61.0^{\circ} \mathrm{S}$ to ca $59.0^{\circ} \mathrm{S}$. At the start of the study the outer ice edge regions were five- to seven-tenths ice covered, and the predominant ice was new ice (pancake and nilas) and young sea ice thinner than $30 \mathrm{~cm}$ (Navy-NOAA Joint Ice Center, Suitland). Sea surface temperatures south

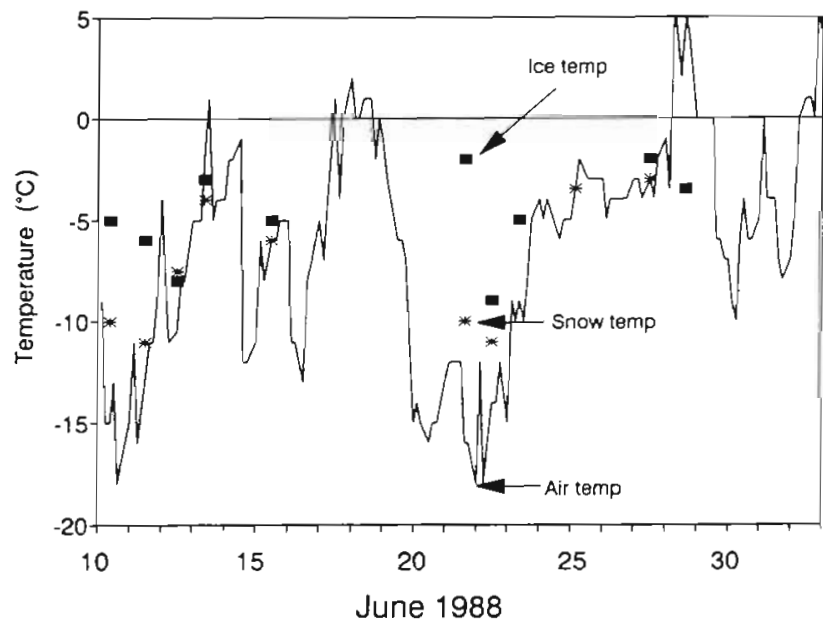

Fig. 2. Temperatures recorded during Leg I of the AMERIEZ 88 cruise. Air: line; snow: * i ice surface: of $59^{\circ}$ were below $-1.46^{\circ} \mathrm{C}$ and salinity was usually within the range of 33.996 to $34.171 \%$ (e.g. Muench et al. 1990). Ice formation and the presence of extensive areas covered by newly formed ice (i.e. nilas or pancake ice) were frequently observed. Atmospheric temperatures showed considerable variability ranging from a low of $-18^{\circ} \mathrm{C}$ to above freezing temperatures (Fig. 2). Temperatures taken on ice floes within snow cover, at the ice surface, and in surface brine samples were often warmer than corresponding air temperatures, suggesting some lag time in the response of ice temperature to transient low atmospheric temperatures (Figs. $2 \& 3$, Cores 09, $04 \& 42$ ).

At the latitude of the study (ca 59 to $61^{\circ} \mathrm{S}$ ), the light day was around $7 \mathrm{~h}$. Solar radiation measurements aboard ship indicated considerable day-to-day variability with incident PAR usually ranging from 3 to $15 \mathrm{E} \mathrm{m}^{-2} \mathrm{~d}^{-k}$ (Lizotte \& Sullivan 1991). Instantaneous radiation was usually within 100 to $500 \mu \mathrm{E} \mathrm{m} \mathrm{m}^{-2} \mathrm{~s}^{-1}$ averaged over the light period, but with peak intensity reaching $1500 \mu \mathrm{E} \mathrm{m}^{-2} \mathrm{~s}^{-1}$.

\section{Ice structure and characteristics}

Samples ranging from newly forming ice through first-and multi-year ice floes were collected (Table 1; Fig. 4). Ice samples classified as 'new' ice were $<20 \mathrm{~cm}$ in thickness. Consolidated new ice floes consisted of both pancake and nilas ice. New ice was often free of snow cover. Young ice, consolidated floes of 30 to $50 \mathrm{~cm}$ thickness, were probably formed in the late aus- 

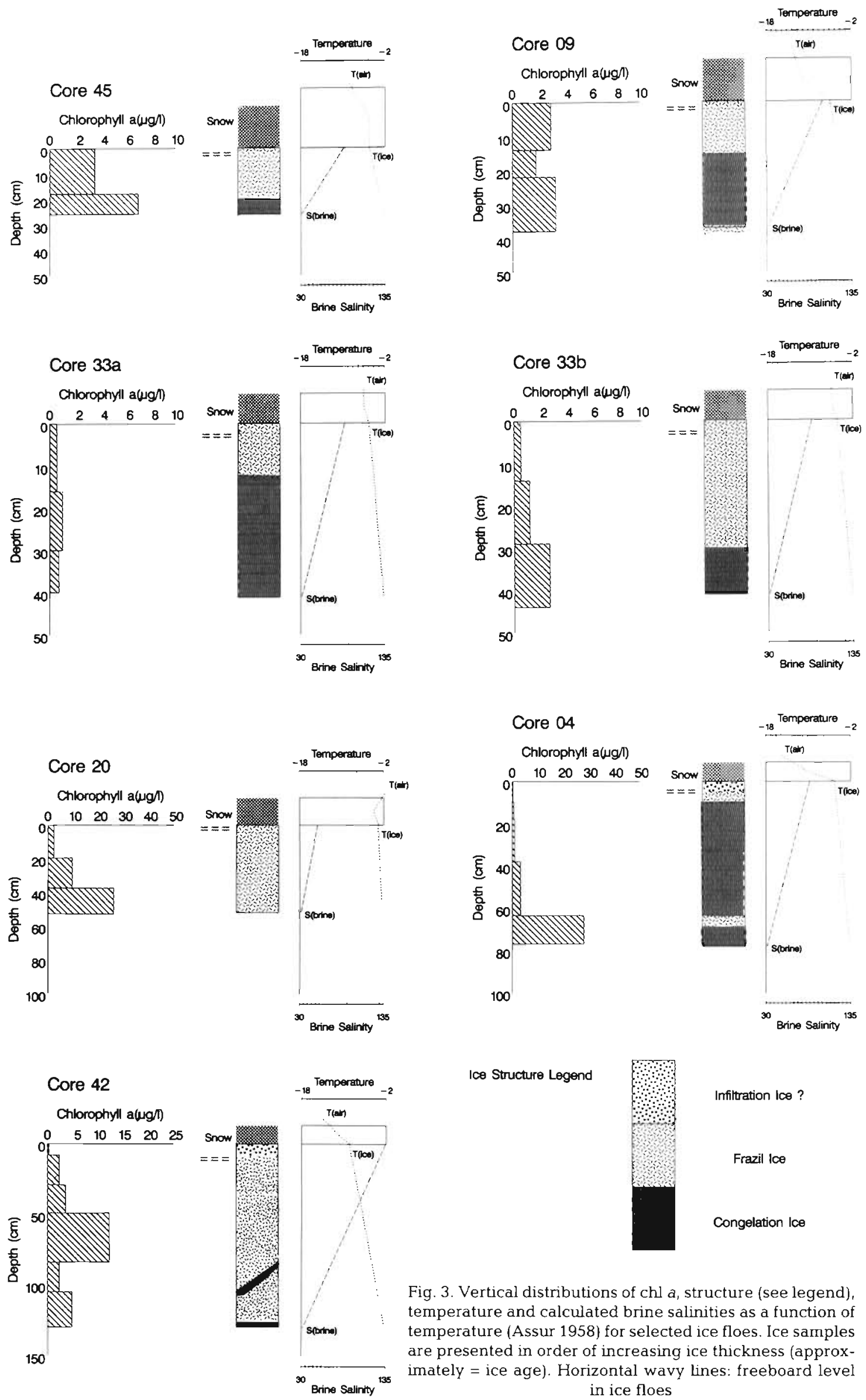

Ice Structure Legend

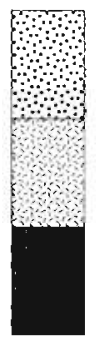

Infiltration Ice ?

Frazil lce

Congelation lce

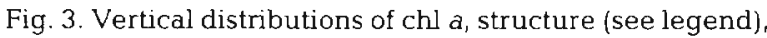
temperature and calculated brine salinities as a function of temperature (Assur 1958) for selected ice floes. Ice samples are presented in order of increasing ice thickness (approximately = ice age). Horizontal wavy lines: freeboard level in ice floes 


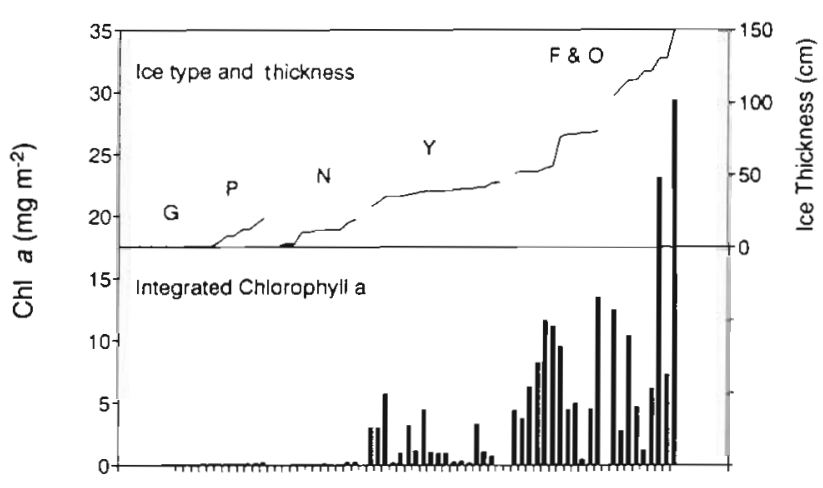

Fig. 4. Summary of ice type and thickness (upper panel)

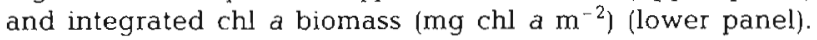
G: grease ice; P: pancake ice; $\mathrm{N}$ : light and dark nilas ice; $Y$ : young sea ice $<50 \mathrm{~cm}$ thick; F \& O: first-year and older sea ice. Ice classification according to Stringer et al. (1984)

tral autumn of early winter of 1988 in the general region of the study. These floes were usually snow covered with snow depth ranging from 0 to $23 \mathrm{~cm}$. Thicker ice floes (i.e. 51 to $149 \mathrm{~cm}$ ) were comprised of ice that apparently survived from the previous summer and may have been advected into the study area from higher latitude regions in the Weddell Sea as the result of clockwise circulation of the Weddell gyre. Snow cover on first-year and older floes ranged from 9 to $54 \mathrm{~cm}$.

Structural analysis on 13 cores showed 5 cores comprised primarily of frazil (granular) ice, 5 cores primarily of congelation (columnar) ice and 3 with approximately equal mixtures. Overall, congelation ice comprised $56 \%$ of the samples, frazil ice comprised $41 \%$ and 3 cores had large angular grained granular ice at the snow-ice interface that we believe was infiltration ice (Fig. 3, Cores $04 \& 42$ ); infiltration ice made up only about $3 \%$ of the cores examined. Nilas ice often contained a frazil surface layer with underlying congelation ice and some of the larger pancakes also showed a transition from frazil to congelation ice with depth. Freeboard levels in floes ranged from 0 to $10 \mathrm{~cm}$ and about half of the floes we sampled had freeboard levels that coincided with the ice surface. The ratio of snow depth to ice thickness ranged from 0 to 0.9 , and about half of the cores were in the range of 0.26 to 0.50 and greater indicating a high potential for surface flooding (Lange et al. 1990).

Bulk ice salinity decreased as a function of ice age, averaging $16.5,6.9,5.4$ and $3.9 \%$ in newly forming, young, first-year and older (both $<100$ and $>100 \mathrm{~cm}$ ), respectively. Surface brine salinity ranged from 35.6 to $104 \%$; these values generally corresponded to predictions of salinity based on temperature (Assur 1958). Examples of the extrapolated in situ temperature and corresponding brine salinity gradients throughout ice floes are shown in Fig. 3. Based on these temperature gradients and bulk salinity measurements (Frankenstein \& Garner 1967), the calculated brine volumes within the ice ranged between ca 3 to $27 \%$ and averaged $11 \%$ over all the ice samples.

\section{Chl $a$, POC, PON and ATP}

Integrated chl a stocks in sea ice increased with ice thickness (Fig, 4). Integrated stocks in new sea ice were $<0.01 \mathrm{mg}$ chl a m $\mathrm{m}^{-2}$. Nevertheless average concentrations in newly forming sea ice $\left(0.69 \mu \mathrm{g} \mathrm{chl} \mathrm{a} \mathrm{l}^{-1}\right.$; Table 2) were 4 to 5 times higher than in the underlying waters as reported by Cota et al. (1992). Integrated chlorophyll stocks in young ice averaged $1.67 \mathrm{mg}$ chl a $\mathrm{m}^{-2}$ and showed considerable variability among samples (Fig. 4); concentrations among samples from these floes averaged $4.24 \pm 4.92 \mu \mathrm{g}$ chl a $\mathrm{l}^{-1}$. The maximum chlorophyll biomass was in thick (multi-year) floes with the highest biomass reaching $29.3 \mathrm{mg} \mathrm{chl} \mathrm{a} \mathrm{m}^{-2}$ and with chl a concentrations exceeding $50 \mu \mathrm{g} \mathrm{l}^{-1}$.

There was a general trend for an increase in chl $a$, POC, PON and ATP concentrations with increasing ice age (Table 2). Average chl a, POC and PON concentrations were significantly different between newly formed, young and first-year and older ice; however, no differences were found between first-year and older ice (both $<100$ and $>100 \mathrm{~cm}$ ) (analysis of variance on log-transformed data followed by Duncan Multiple Range test; $\alpha=0.05$ ). ATP followed a similar pattern except that concentrations in young sea ice were intermediate between, and not significantly different from, newly formed ice or first-year and older ice. Among types of newly formed ice (i.e. grease, pancake and nilas), only the $\mathrm{C}$ : chl $\mathrm{a}$ in nilas ice was significantly different from the other 2 ice types. When testing for significant differences in $\mathrm{C}: \mathrm{chl} a, \mathrm{C}: \mathrm{N}$ and $\mathrm{C}$ :ATP among newly forming, young, first-year and older ice (both $<100$ and $>100 \mathrm{~cm}$ ), we found that only the higher $\mathrm{C}: \mathrm{chl}$ a ratio in newly forming ice and the higher $\mathrm{C}: \mathrm{N}$ ratios in newly formed and older ice floes $>100 \mathrm{~cm}$ were significantly different from the other types of ice (ANOVA and Multiple Range Test as above but without log transformation of data). There was no significant difference in chlorophyll concentrations among the different structural types of ice (infiltration, frazil, congelation and mixed ice types).

\section{Composition of winter ice assemblage}

Overall, diatoms dominated the biomass of the ice assemblage. Nitzschia species including $N$. cylindrus, $N$. prolongatiodes, $N$. closterium and Chaetoceros 
Table 2. Summary of bulk chemical parameters of the ice biota. Chl a, POC, PON and ATP concentrations are $\mu \mathrm{g} \mathrm{l^{-1 }}$. $\mathrm{C}: \mathrm{N}$ is molar ratio. $n$ : number of samples for this ice type. The ratios of parameters were calculated for individual records in the data set before calculating summary statistics, and these sometimes have a lower $\mathrm{n}$ because of missing values. Thus, the ratio of the mean values will not be the same as the mean of ratios

\begin{tabular}{|c|c|c|c|c|c|c|c|}
\hline Ice type & Chl a & POC & PON & ATP & $\mathrm{C}: \mathrm{Chl}$ & $C: N$ & C:ATP \\
\hline \multicolumn{8}{|c|}{ Water column samples ${ }^{a}$} \\
\hline Mean & 0.12 & 62.5 & 7.1 & - & 530 & 10 & - \\
\hline \multicolumn{8}{|c|}{ Newly formed sea ice } \\
\hline $\begin{array}{c}\text { Grease ice: } \\
n\end{array}$ & (3) & (3) & (3) & (2) & (3) & (3) & (2) \\
\hline Mean $\pm \mathrm{SD}$ & $0.89 \pm 0.54$ & $433 \pm 103$ & $33 \pm 33$ & $0.25 \pm 0.18$ & $645 \pm 385$ & $17 \pm 8$ & $1960 \pm 1114$ \\
\hline \multicolumn{8}{|l|}{ Pancake ice: } \\
\hline Mean \pm SD & $0.87 \pm 0.35$ & $471 \pm 119$ & $41 \pm 14$ & - & $539 \pm 235$ & $14 \pm 4$ & - \\
\hline \multicolumn{8}{|l|}{ Nilas ice: } \\
\hline n & (11) & (5) & (5) & - & (5) & (5) & - \\
\hline Mean $\pm \mathrm{SD}$ & $0.49 \pm 0.40$ & $687 \pm 251$ & $54 \pm 21$ & - & $4014 \pm 2006$ & $16 \pm 7$ & - \\
\hline \multicolumn{8}{|c|}{ Young sea ice $(20$ to $50 \mathrm{~cm})$} \\
\hline $\mathrm{n}$ & $(44)$ & (24) & $(24)$ & (24) & (23) & (24) & $(22)$ \\
\hline Mean $\pm S D$ & $4.24 \pm 4.92$ & $1171 \pm 831$ & $153 \pm 102$ & $1.36 \pm 1.70$ & $708 \pm 1386$ & $10 \pm 7$ & $1479 \pm 1105$ \\
\hline \multicolumn{8}{|c|}{ First year and older ice $(<100 \mathrm{~cm})$} \\
\hline $\mathrm{n}$ & $(46)$ & (30) & $(30)$ & (21) & $(30)$ & (30) & (21) \\
\hline Mean $\pm \mathrm{SD}$ & $9.75 \pm 11.5$ & $2208 \pm 1523$ & $269 \pm 223$ & $1.9 \pm 1.6$ & $469 \pm 532$ & $11 \pm 3$ & $1651 \pm 1262$ \\
\hline \multicolumn{8}{|c|}{ First year and older ice $(>100 \mathrm{~cm})$} \\
\hline$n$ & $(50)$ & (25) & $(25)$ & (17) & $(25)$ & $(25)$ & $(17)$ \\
\hline Mean $\pm \mathrm{SD}$ & $8.74 \pm 11.5$ & $2097 \pm 1023$ & $195 \pm 122$ & $2.2 \pm 2.0$ & $769 \pm 1117$ & $14 \pm 5$ & $1323 \pm 615$ \\
\hline
\end{tabular}

neogracile were present in most samples and dominated the diatom biomass and cell numbers (Table 3). Autotrophic dinoflagellates and other autotrophic flagellates comprised a smaller but significant fraction of the autotrophic biomass. Archaeomonads dominated the numbers and biomass of the non-dinoflagellate autotrophic flagellates. Prymnesiophytes (including but not limited to the motile stage of Phaeocystis pouchetii), cryptophytes and prasinophytes were also abundant (Table 3). Athecate dinoflagellates could not be reliably separated into autotrophic and heterotrophic forms in settled samples, so oniy Prorocentrum and hypnozygotes of an athecate autotrophic dinoflagellate (Buck et al. 1992) are included in Table 3. However, counts of filter-concentrated brine using epifluorescence microscopy indicated that ca $80 \%$ of the dinoflagellates present were heterotrophic (range 42 to $99 \%$ of cell numbers or 15 to $97 \%$ of the biomass). Overall $\mathrm{C}$ : chl a ratios averaged 28 with a range of 7 to 62 , based on carbon estimated from cell volume and abundance determinations. (The autotrophic carbon estimates included diatoms, archaeomonads, autotrophic flagellates, dinoflagellate hypnozygotes, and the ciliate Mesodinium rubrum.)

Bacteria were present in abundances ranging from $2 \times 10^{5}$ to $1 \times 10^{7}$ cells $\mathrm{ml}^{-1}$ with biomass averaging $41 \mu \mathrm{g} \mathrm{C} \mathrm{l}^{-1}$. Heterotrophic dinoflagellates, entirely comprised of athecate forms, dominated the protozoan biomass. Except in isolated samples, choanoflagellates and other heterotrophic nanoflagellates were a minor fraction of the heterotrophic biomass. Ciliates were the only other abundant heterotrophic group present. Foraminiferans, amoeba, and naupliar larval stages of copepods were present in a few samples but were usually in low abundance (Table 3).

Overall community composition for 7 ice cores is summarized in Fig. 5. The comparison of integrated POC and the biota analysis suggested that living (intact and recognizable) organisms comprised from 15 to $30 \%$ of the carbon in ice floes. Carbon estimates from microscopy generally agreed with carbon estimated from ATP (i.e. Carbon $=$ ATP $\times 250$; HolmHansen \& Karl 1978).

\section{DISCUSSION}

\section{Community composition and biomass}

There have been an increasing number of studies in the pack ice regions of Antarctica, but data on the composition of the ice assemblage and information about seasonal population dynamics are still relatively scarce (e.g. reviewed by Garrison 1991). Biomass estimates 
Table 3. Summary of abundance and biomass of taxa comprising the winter assemblage. $N$ : frequency of occurrence out of 28 samples examined. Except for Other Protozoa and Metazoa (which were found in relatively few samples) group means and ranges are also for 28 ice samples. Data are from melted ice samples and were obtained from examination using an inverted microscope, except where indicated. Average and range are summarized for major taxonomic groups

\begin{tabular}{|c|c|c|c|c|c|c|c|}
\hline Species & $N$ & $\begin{array}{c}\text { Abundance } \\
\left(\text { no }, 1^{-1}\right)\end{array}$ & $\begin{array}{l}\text { Biomass } \\
\left(\mu \mathrm{g} \mathrm{Cl}^{-1}\right)\end{array}$ & Species & $\mathrm{N}$ & $\begin{array}{c}\text { Abundance } \\
\left(\text { no. } 1^{-1}\right)\end{array}$ & $\begin{array}{c}\text { Biomass } \\
\left(\mu \mathrm{g} \mathrm{Cl}^{-1}\right)\end{array}$ \\
\hline \multicolumn{4}{|l|}{ Diatoms } & \multicolumn{4}{|l|}{ Choanoflagellates } \\
\hline Nitzschia cylindrus & 25 & $1.17 \times 10^{7}$ & 143.0 & Diaphanoeca multiannulata & 9 & $5.86 \times 10^{5}$ & 4.4 \\
\hline Nitzschia lecointei & 2 & $2.93 \times 10^{6}$ & 101.1 & Bicosta spinifera & 1 & $2.50 \times 10^{5}$ & 0.9 \\
\hline Amphiprora kjellmannii & 17 & $2.43 \times 10^{5}$ & 50.7 & Choanoflagellate (misc.) & 6 & $7.29 \times 10^{4}$ & 0.5 \\
\hline Nitzschia (Fragilariopsis) & 14 & $6.29 \times 10^{5}$ & 45.6 & Calliacantha simplex & 1 & $9.30 \times 10^{4}$ & 0.3 \\
\hline Dactyliosolen tenuijunctum & 4 & $5.40 \times 10^{5}$ & 42.5 & Parvicorbicula socialis & 1 & $7.80 \times 10^{4}$ & 0.2 \\
\hline Corethron criophilum & 17 & $7.37 \times 10^{4}$ & 35.1 & Bicosta antennigera & 1 & $3.10 \times 10^{3}$ & 0.0 \\
\hline Chaetoceros neogracile & 24 & $1.89 \times 10^{6}$ & 24.4 & Average & & $2.50 \times 10^{5}$ & 2 \\
\hline Actinocyclus actinochilus & 6 & $1.81 \times 10^{4}$ & 19.0 & Minimum & & 0.00 & 0 \\
\hline Nitzschia turgiduloides & 15 & $3.91 \times 10^{5}$ & 18.9 & Maximum & & $4.60 \times 10^{6}$ & 34 \\
\hline Nitzschia closterium & 23 & $4.51 \times 10^{5}$ & 16.1 & \multicolumn{4}{|c|}{ Other heterotrophic nanoflagellates ${ }^{\star}$} \\
\hline Nitzschia prolongatoides & 23 & $1.85 \times 10^{6}$ & 11.6 & Heterotrophic flagellates & 23 & $2.47 \times 10^{5}$ & 2.2 \\
\hline Synedra sp. & 13 & $2.19 \times 10^{5}$ & 10.7 & Cryothecomonas sp. & 5 & $5.64 \times 10^{3}$ & 0.7 \\
\hline Rhizosolenia alata & 18 & $1.28 \times 10^{4}$ & 8.3 & Average & & $2.30 \times 10^{5}$ & 2 \\
\hline Tropidonels fusiformis & 11 & $4.44 \times 10^{4}$ & 5.5 & Minimum & & 0.00 & 0 \\
\hline Chaetoceros dichaeta & 13 & $5.79 \times 10^{4}$ & 4.6 & Maximum & & $1.40 \times 10^{6}$ & 10 \\
\hline Tropidoneis gaussij & 11 & $1.69 \times 10^{4}$ & 3.6 & \multicolumn{4}{|c|}{ Heterotrophic dinoflagellates ${ }^{\text {a }}$} \\
\hline Nitzschia subcurvata & 3 & $5.34 \times 10^{4}$ & 2.4 & Gymnodinium sp. & 22 & $5.49 \times 10^{4}$ & 31.1 \\
\hline Tropidoneis glacialis & 1 & $8.10 \times 10^{3}$ & 2.2 & Gyrodinium sp. & 1 & $4.50 \times 10^{2}$ & $\begin{array}{r}01.1 \\
2.8\end{array}$ \\
\hline Tropidoneis belgicae & 3 & $3.18 \times 10^{3}$ & 1.8 & Amphidinium sp. & 1 & $2.60 \times 10^{2}$ & $\begin{array}{l}2.0 \\
0.2\end{array}$ \\
\hline Eucampia antarctica & 1 & $2.00 \times 10^{3}$ & 1.7 & Average & & $5.40 \times 10^{4}$ & 39 \\
\hline Thalassiosira sp. & 9 & $9.08 \times 10^{2}$ & 1.3 & Minimum & & 0.03 & $\begin{array}{r}39 \\
0\end{array}$ \\
\hline Nitzschia lineola & 1 & $1.50 \times 10^{4}$ & 1.3 & Maximium & & $2.10 \times 10^{5}$ & 150 \\
\hline Stellarima microtrias & 2 & $3.50 \times 10^{2}$ & 1.2 & \\
\hline Chaetoceros pendulum & 5 & $9.40 \times 10^{3}$ & 0.8 & $\begin{array}{l}\text { Ciliates } \\
\text { Other ciliates }\end{array}$ & 25 & $6.43 \times 10^{3}$ & \\
\hline Average & & $1.70 \times 10^{7}$ & 336 & $\begin{array}{l}\text { Other ciliates } \\
\text { Oligatrichs }\end{array}$ & 16 & $\begin{array}{l}0.43 \times 10 \\
1.00 \times 10^{3}\end{array}$ & 7.7 \\
\hline Mimimum & & $1.80 \times 10^{5}$ & 2 & $\begin{array}{l}\text { Oligotrichs } \\
\text { Mesodinium rubrum }\end{array}$ & 1 & $3.00 \times 10^{2}$ & 1.4 \\
\hline Maximum & & $9.10 \times 10^{7}$ & 1700 & $\begin{array}{c}\text { Mesodinium rubrum } \\
\text { Average }\end{array}$ & & $7.30 \times 10^{3}$ & $\begin{array}{l}0.1 \\
9\end{array}$ \\
\hline Autotrophic flagellates ${ }^{a}$ & & & & $\begin{array}{l}\text { Average } \\
\text { Minimum }\end{array}$ & & $5.60 \times 10^{2}$ & $\begin{array}{r}9 \\
<1\end{array}$ \\
\hline Archaeomonads & 17 & $1.57 \times 10^{6}$ & 21 & $\begin{array}{l}\text { Mummum } \\
\text { Maximum }\end{array}$ & & $2.70 \times 10^{4}$ & $\begin{array}{l}<1 \\
37\end{array}$ \\
\hline Phaeocystis pouchetii & 16 & $7.28 \times 10^{5}$ & 9 & \multirow{2}{*}{\multicolumn{4}{|c|}{ Other Protozoa }} \\
\hline Cryptomonads & 3 & $1.83 \times 10^{4}$ & 1 & & & & \\
\hline Prasinophytes & 6 & $3.66 \times 10^{4}$ & 1 & Foraminifera & 4 & $1.26 \times 10^{3}$ & 0.6 \\
\hline Mantoniella sp. & 3 & $6.47 \times 10^{4}$ & $>1$ & Amoebae & 1 & $7.70 \times 10^{5}$ & \\
\hline Average & & $1.90 \times 10^{6}$ & 26 & Average & & $1.30 \times 10^{3}$ & \\
\hline Minimum & & 0.00 & 0 & Minimum & & $4.70 \times 10^{1}$ & 0.6 \\
\hline Maximum & & $1.30 \times 10^{7}$ & 237 & Maximum & & $3.20 \times 10^{3}$ & 1.2 \\
\hline \multicolumn{4}{|l|}{ Autotrophic dinoflagellates ${ }^{a}$} & \multicolumn{4}{|l|}{ Metazoa } \\
\hline Prorocentrum sp. & 4 & $5.07 \times 10^{4}$ & 46.6 & Nauplius larvae & 6 & $3.74 \times 10^{2}$ & 7.7 \\
\hline Hypnozygotes & 7 & $1.17 \times 10^{4}$ & 0.8 & Minimum & & $2.40 \times 10^{1}$ & 2.9 \\
\hline Average & & $1.10 \times 10^{4}$ & 8 & Maximum & & $9.20 \times 10^{2}$ & 18.0 \\
\hline Minimum & & 0.00 & 0 & Miscellaneous & & & \\
\hline Maximum & & $1.30 \times 10^{5}$ & 15 & Fecal pellets & 18 & $1.85 \times 10^{4}$ & \\
\hline
\end{tabular}

based on measuring chl a concentrations are often the only community biomass measurements available, and these only account for autotrophic forms. Measurements of POC, PON and ATP have been widely used in other habitats to provide additional information about community composition; however, there are few measurements from Antarctic sea ice (e.g. Bunt \& Lee 1970 , Palmisano \& Sullivan 1983). The high C:chl, C:N and
C:ATP ratios that we observed in winter pack ice (Table 2) suggest considerable carbon contribution from heterotrophs and detritus. We expected to see evidence of detrital accumulation in old sea ice, reflected by high $\mathrm{C}: \mathrm{N}, \mathrm{C}: \mathrm{chl}$ and $\mathrm{C}$ :ATP ratios (Table 2 ), but we did not anticipate finding such high ratios in young ice. This may be the result of nonselective harvesting and concentration of organisms and detritus 
from the water column during ice formation, since high $\mathrm{C}: \mathrm{chl} a$ and $\mathrm{C}: \mathrm{N}$ ratios were also found in the water column (Table 2 and Cota et al. 1992). The particulate material in the water may have originated from older ice floes and then been reincorporated into new ice. Both ice formation and melting were observed within the study area (Muench et al, 1990, Garrison et al. 1992), although during winter, ice formation would be expected to predominate. Melting may be more apparent in the dynamic region of the Weddell/Scotia Sea confluence (Muench et al. 1990).

More specific information about community composition can be derived from making counts of organisms by microscopy and estimating carbon biomass from size and carbon:volume relationships (e.g. Garrison \& Buck 1989). However, this approach is time consuming and the potential for biased estimates (e.g. Garrison \& Buck 1986) makes it difficult to evaluate the accuracy of microscopy-based biomass estimates without corroborating data. Our estimates of living biomass based on ATP (Fig. 5) were in close agreement with our microscopy estimates and give us additional confidence in our ability to define accurately the community composition. As we have observed in other seasons (Garrison \& Buck 1989), the biomass concentrations in sea ice are considerably higher than in the underlying water column (Garrison et al. 1993), and during the winter, the ice community may be a particularly important food source for some pelagic consumers. During the AMERIEZ winter cruise, Daly (1990) was able to show that juvenile Euphausia superba feed on the ice biota and argued that they would only be able to achieve observed winter growth rates by utilizing this resource. Moreover, she also concluded that the het- erotrophic organisms in ice (e.g. protozoans) were a significant fraction of the ration consumed by grazing juvenile stages of krill. Daly \& Macaulay (1991) also point out that, although feeding on the ice biota may be critical to larval stages of krill which cannot overwinter without feeding, the adults may have other overwintering strategies. Garrison et al. (1993) also speculated that organisms and detritus released from ice by melting of floes at the northern extent of the icecovered regions could be a significant contribution to carbon biomass in the water column and may account for the predominance of heterotrophic microplankton comprising the planktonic assemblages.

Species assemblages were extremely variable among ice samples, and the winter assemblage (Table 3) does not appear to differ markedly from those we have reported from previous studies in the pack ice regions of the Weddell Sea (e.g. Garrison et al. 1987, Garrison \& Buck 1989). Resting stages of unknown chrysopytes (i.e. archaeomonads: Mitchell \& Silver 1982, Garrison \& Buck 1989) and dinoflagellate cysts (Buck et al. 1992) were common. As we have observed in previous studies (Garrison \& Buck 1989), archaeomonads were sometimes abundant in surface-layer samples, which would be consistent with the report that these are formed in the late summer (Stoecker et al 1990). Most autotrophic dinoflagellates were present as 'cysts' and they were distributed throughout floes, so some of these cysts must have formed in the autumn and early winter. Athecate dinoflagellates, similar to those that we have observed to form cysts in culture (Buck et al. 1992), were abundant in the winter plankton assemblage (Garrison et al. 1993), but high concentrations of cysts were only found in sea ice,
Fig. 5. Integrated particulate organic carbon (POC), living biomass estimated from microscopy for bacteria (Bact), protozoans (Pzoo) and ice algae (Auto). Alternate estimate of living carbon as solid line across bars estimated from integrated ATP concentrations $\times 250$ (Holm-Hansen \& Karl 1978). All values are $\mathrm{mg} \mathrm{C} \mathrm{m} \mathrm{Cm}^{-2}$ integrated over individual floe thickness. Numbers at bottom of figure refer to core numbers, plotted in order of increasing thickness (Table 1). Note the scale changes on the graphs and that $\mathrm{POC}$ for Core 40 is off the scale. Cores 44 to 30 $(<50 \mathrm{~cm})$ are probably autumn or winter ice formed during 1988. The remainder of floes are first-year and possibly multi-year ice from previous seasons
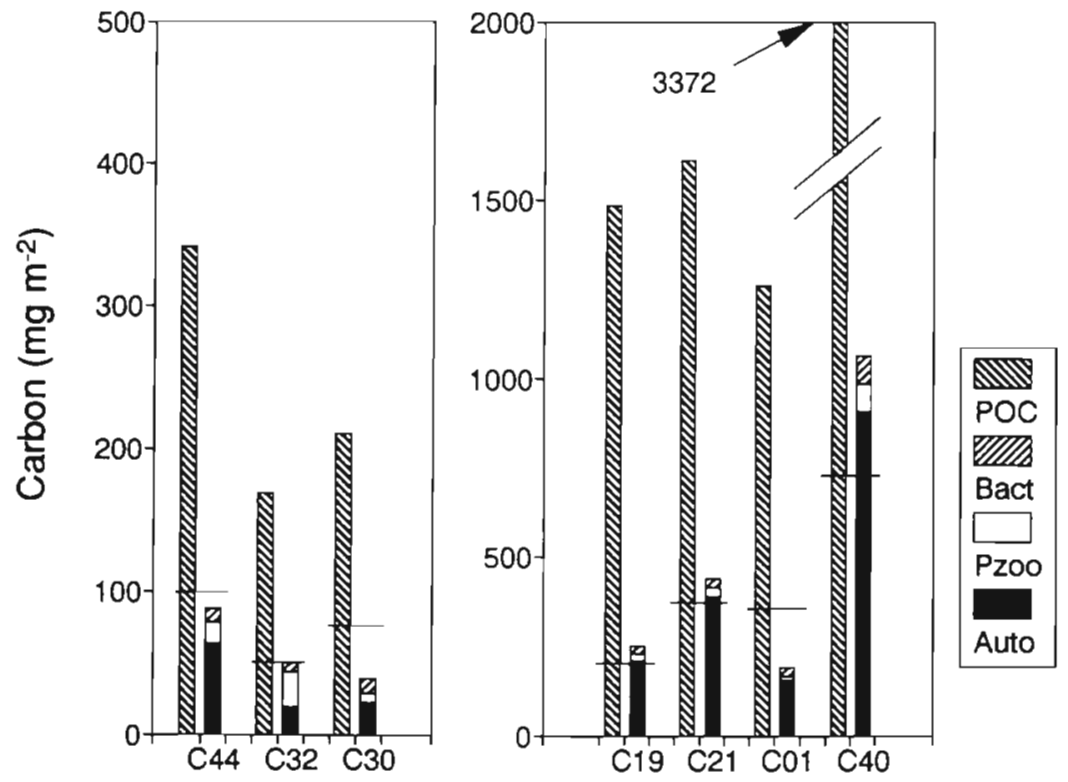
perhaps suggesting that these were formed in ice rather that incorporated during ice formation. There is presently little information about the role of either of these 'resting stages' in ice community dynamics. Unfortunately, we did not examine organisms from newly forming ice, and it would have been interesting to see if any of these resting stages were incorporated from the water or formed during ice formation. The melting of older ice and the subsequent incorporation of this material in new ice (discussed above) may provide a reliable mechanism for reestablishing populations in annually forming sea ice.

\section{Seasonality}

Our observations from 3 cruises provide some basis for examining the seasonality of the pack ice biota. We anticipated that winter biomass of the ice biota would be near the seasonal minimum. However, chl a concentrations from winter ice differed little from measurements during other seasons (e.g. Garrison \& Buck 1989, Dieckmann et al. 1990). Chl $a$, POC and PON show a tendency for increasing concentrations as a function of ice age (i.e. thickness), but these vary only from about 4 - to 10 -fold from new ice through ice $>1 \mathrm{yr}$ old (Table 2). As we observed for bulk measurements (e.g. chl a and POC), microscopy estimates of the biomass (Fig. 6) or abundances (Fig. 7) of major groups also show little seasonality. Although we have few samples with data throughout ice floes in the spring and late summer (Fig. 6), we believe there is an increase in heterotrophs in some ice habitats. This impression is reinforced by our finding highly concentrated, but relatively rare, heterotroph-dominated assemblages in the surface layer habitat during the spring (Garrison \& Buck 1989, 1991) and late summer (Buck et al. 1989, Garrison \& Buck 1989). These well- developed surface layer assemblages were not found during the winter.

The lack of strong seasonal biomass change in pack ice may be a result of the predominance of internal assemblages, which appear to remain as an isolated habitat for much of the year (Garrison et al. 1986, Garrison \& Buck 1989, 1991, Dieckmann et al. 1990). In this aspect, the pack ice assemblages are considerably different from land-fast ice assemblages where biomass varies by 2 to 3 orders of magnitude from minimal to maximal concentrations (e.g. Palmisano \& Sullivan 1983, Arrigo et al. 1991).

Our abundance data for copepod nauplii and foraminifera (Other Protozoa in Fig. 6) are in general agreement with data reported by Spindler et al. (1990), but our ciliate numbers are, on average, an order of magnitude greater. We do not know if this reflects different analytical techniques or different community structure in the higher latitude regions where the German studies were centered (e.g. mostly 70 to $75^{\circ} \mathrm{S}$ and with some stations in land-fast ice). As we discuss later, there may be latitudinal differences in the physical conditions throughout the ice covered regions.

\section{Winter ecology of the sea ice community}

The Antarctic winter is characterized by seasonal minima of temperature and solar radiation, and both may result in conditions unfavorable for growth and survival in some sea ice habitats (Kottmeier \& Sullivan 1987, 1988, Bartsch 1989, Eicken 1992). On the other hand, this is also a period of rapid ice formation and growth and may be the time when organisms are first established in pack ice floes. Thus, understanding the process of incorporation and knowing conditions for winter survival and/or activity may be fundamental

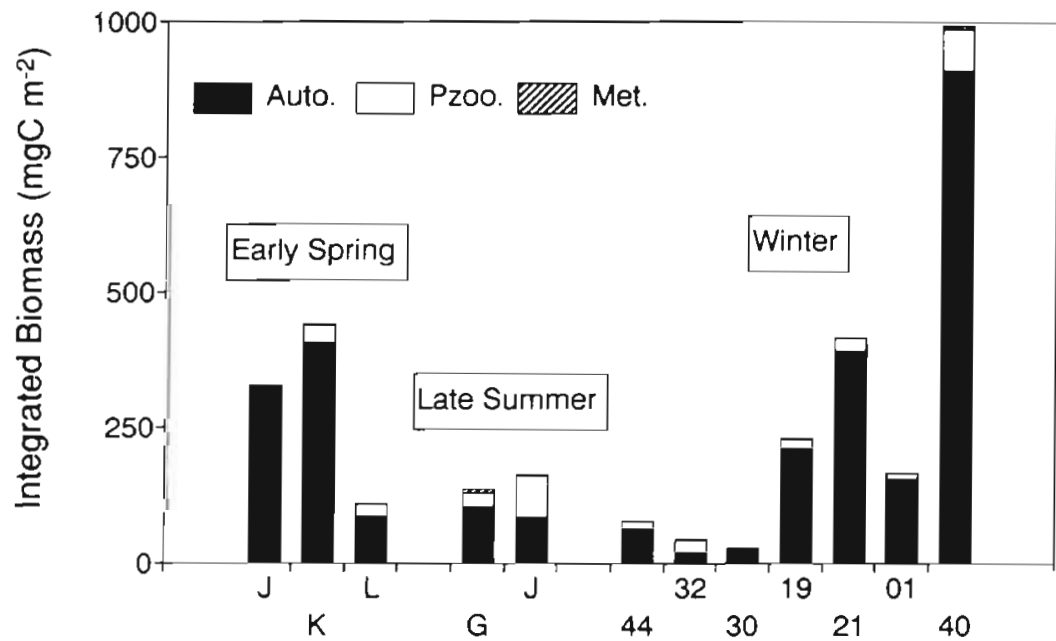

Fig. 6. Early spring (AMERIEZ 83), late summer (AMERIEZ 86), and winter (AMERIEZ 88 , the present study) comparison of integrated biota in sea ice floes. Ice floes from AMERIEZ 83 and 86 are all first-year ice. Winter ice core samples are described in Fig. 5 legend. Cores are identified by letter or number at the bottom of the figure. Auto.: ice algae; Pzoo.: protozoans; Met.: metazoans 

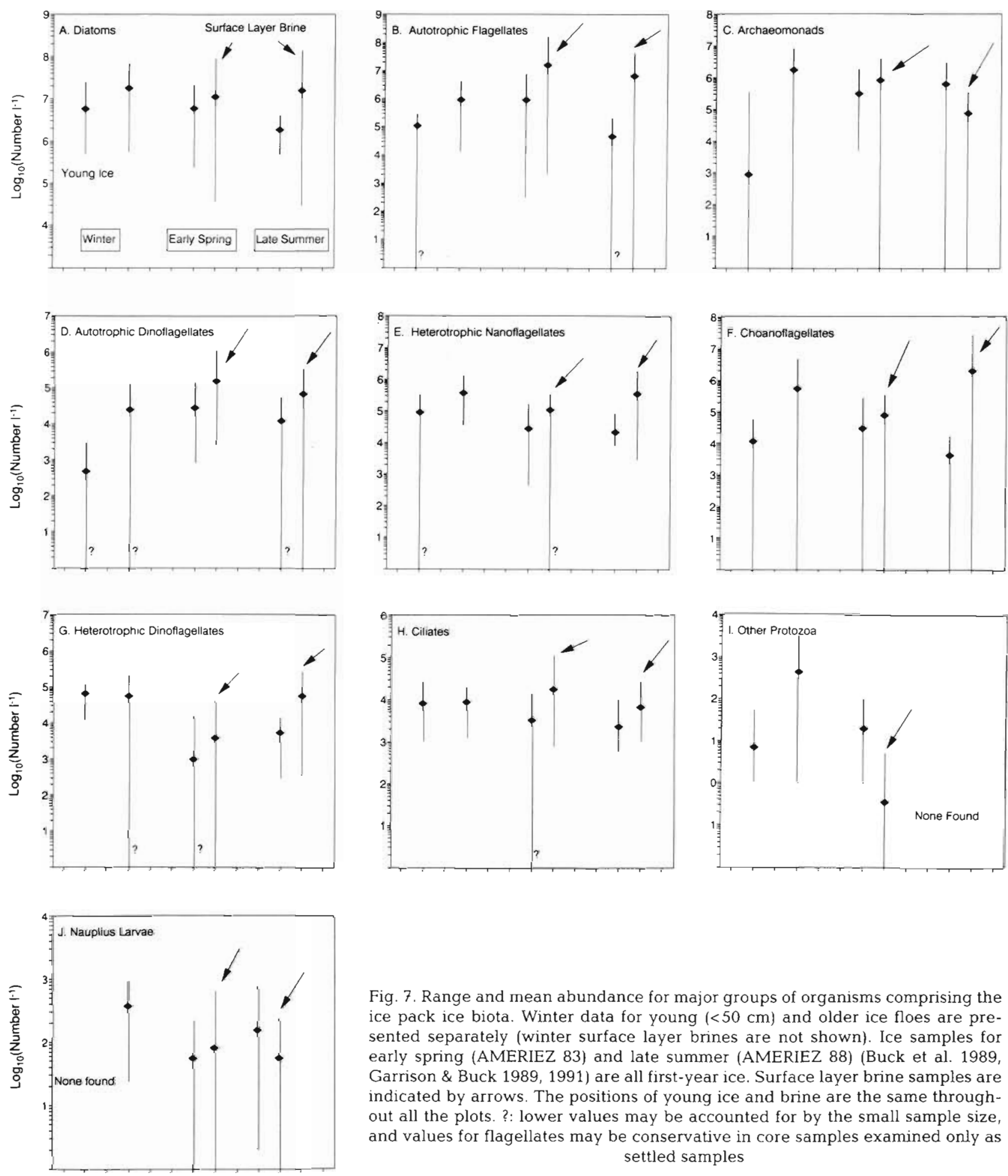

Fig. 7. Range and mean abundance for major groups of organisms comprising the ice pack ice biota. Winter data for young $(<50 \mathrm{~cm})$ and older ice floes are presented separately (winter surface layer brines are not shown). Ice samples for early spring (AMERIEZ 83) and late summer (AMERIEZ 88) (Buck et al. 1989, Garrison \& Buck 1989, 1991) are all first-year ice. Surface layer brine samples are indicated by arrows. The positions of young ice and brine are the same throughout all the plots. ?: lower values may be accounted for by the small sample size, and values for flagellates may be conservative in core samples examined only as settled samples

to understanding seasonal dynamics of the pack ice community.

One of the fundamental features of the pack ice habitat is the high percentage of frazil ice incorporated in ice floes (e.g. Clarke \& Ackley 1984, Gow et al. 1987, Eicken \& Lange 1989). The frequent production of frazil ice and the harvesting and concentration of material associated with this process (Garrison et al. 1983, 1989), have been used to explain the widespread occurrence of internal assemblages throughout the pack ice (e.g. Ackley et al. 1979, Garrison et al. 1986, Garrison 1991). As others have reported from 
different regions of the Weddell Sea, we found that ice floes in the Weddell/Scotia Sea region contained significant amounts of frazil ice (ca $40 \%$ ), and even the youngest ice samples had chl $a, P O C$ and PON concentrations considerably higher than the underlying water column (Table 2, and water column data in Cota et al. 1992). Some of the material in ice floes, including detritus, can be attributed to the harvesting mechanism associated with frazil ice formation, but among all the types of ice that we examined, we did not find significantly higher chl a associated with frazil ice in comparison with congelation ice. Thus, there must be other processes that account for the elevated biomass associated with congelation ice. We suspect that some of the material in sea ice must arise from in situ growth in late autumn and winter. Measurements of bacterial activity (Kottmeier \& Sullivan 1987, 1990) and algal photosynthetic capacity (Lizotte \& Sullivan 1991) indicate bacteria and algae in sea ice are potentiaily active in pack ice throughout the year. These measurements, however, were made on melted ice samples at sea-surface salinities and temperatures and their relationship to in situ activity is unknown. The marked seasonality of photoperiod in polar regions and the attenuation of PAR by snow cover and ice potentially limit ice-based primary production (Grossi et al. 1987. Arrigo et al. 1991). At the highest latitudes where sea ice occurs there are several weeks of complete darkness at midwinter. Although autumn blooms have been reported from these locations (Hoshiai 1981), winter production by photoautotrophs is unlikely. At the Iow latitude extent of drifting pack ice (55 to $60^{\circ} \mathrm{S}$ ), however, measurements and calculation of the light regime in ice suggest sufficient light throughout the sea ice to support in situ production in ice with moderate snow cover (Fig. 8). More precise formulations have been developed to model the light regime in sea ice (Arrigo et al. 1991) but it is not clear that these would necessarily provide more representative estimates of the seasonal light regime because of the inconsistency of variables, e.g. snow cover, which primarily determine attenuation (Lange et al. 1990). Moreover, observations (Irwin 1990, Garrison \& Buck 1991) suggest that significant amounts of light may enter drifting pack ice floes from exposed edges and thus the in situ light conditions may depend on floe size, ice cover and floe distribution as well as the factors that influence vertical attenuation through snow cover and ice.

Light levels may not be the only important variable limiting biological activity in sea ice during winter. Similarly to the gradient of solar radiation, atmospheric temperatures also vary with latitude (Fig. 9), and several workers have recognized that low atmospheric temperatures result in sharp temperature and salinity



Fig. 8. Calculated light regime within pack ice as a function of seasonal total daily PAR $\left(E \mathrm{~m}^{-2} \mathrm{~d}^{-1}\right)$. Isolumes of PAR within sea ice $\left(\mu \mathrm{E} \mathrm{m}^{-2} \mathrm{~s}^{-1}\right)$ are $24 \mathrm{~h}$ averages. Irradiance through ice was calculated assuming an albedo $=0.85,5 \mathrm{~cm}$ of snow with an attenuation of $18 \mathrm{~m}^{-1}$ and an attenuation for sea ice of $0.8 \mathrm{~m}^{-1}$. Range and mean of radiation data collected during AMERIEZ 88 (winter: this study), AMERIEZ 86 (autumn), and AMERIEZ 83 (spring). Radiation data were collected by C. W. Sullivan and reported by Lizotte \& Suilivan (1991) and Cota et al. (1992) 
Fig. 9. Temperature regime of the icecovered regions. Average monthly air temperatures at 3 latitudes at $40^{\circ} \mathrm{W}$ in the Weddell Sea (Taljaard et al. 1969, Zwally et al. 1983) are shown as broken lines. Actual temperature measurements during AMERIEZ 86 (at approximately $65^{\circ} \mathrm{S}$ ), AMERIEZ $88\left(59\right.$ to $61^{\circ} \mathrm{S}$ ) and AMERIEZ 83 (61 to $62^{\circ}$ ) are shown as solid lines

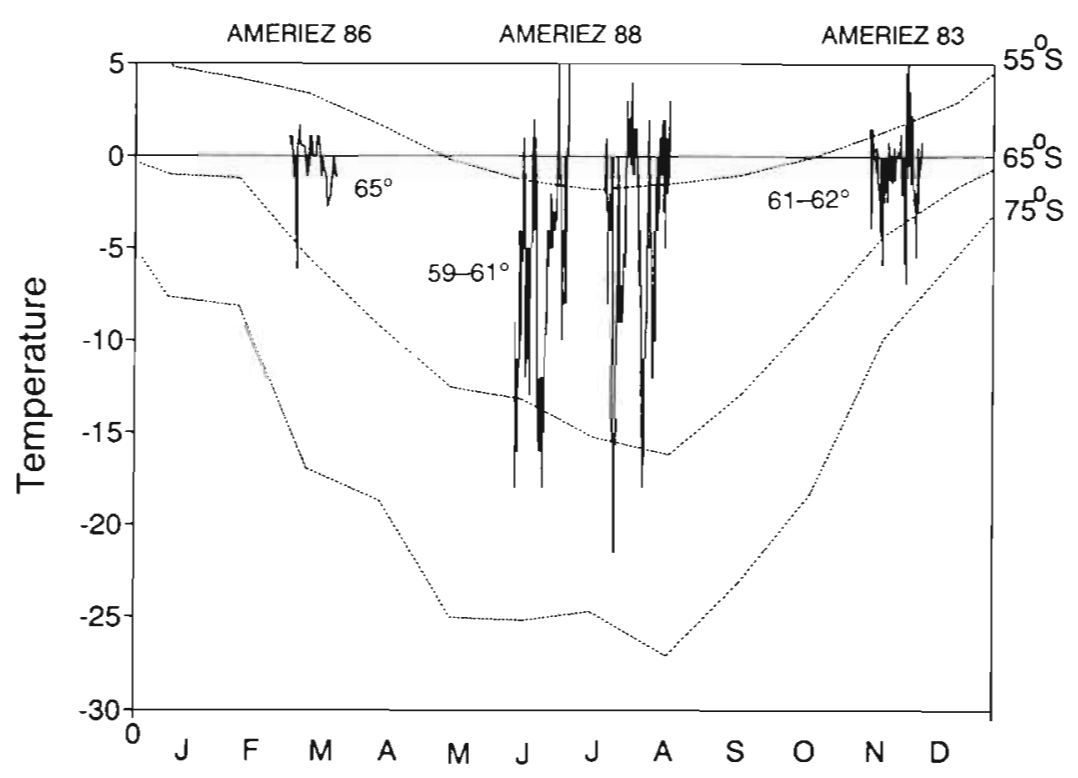

gradients throughout sea ice floes (Meguro et al. 1967. Kottmeier \& Sullivan 1988, Bartsch 1989, Eicken 1992, and see Fig. 3), so that even when light levels in ice exceed the compensation intensity, other conditions may be unfavorable for photosynthesis of algae or for the growth and survival of other ice-associated organisms. For example, experiments by Palmisano et al. (1987) and Kottmeier \& Sullivan (1988) indicated that ${ }^{14} \mathrm{C}$ uptake by algae and ${ }^{3} \mathrm{H}$ uptake by bacteria are depressed at high salinities, but the effect of temperature below $-2{ }^{\circ} \mathrm{C}$ was not tested. In culture growth experiments, Bartsch (1989) found that diatom cell division ceased at $-5.5^{\circ} \mathrm{C}$ or $90 \%$ salinities. Observations during the present study (Fig. 2, and temperature and salinity profiles in Fig. 3) indicate transient conditions where biological activity is likely to be limited by low temperatures and/or high salinities within the ice floes. As we observed for the light regime, there is often considerable variability of temperature within any season (Fig. 9).

As another consequence of lower temperature in sea ice, brine volume will be reduced as an inverse function of temperature. From examining nutrient ratios and comparing them to similar ratios in underlying water (Garrison et al. 1990), we speculated that brine inclusions are isolated from seawater and that nutrient concentrations apparently reflect in situ biological activity. Comparing abundances found in extracted brine and melted ice cores, we also concluded that some organisms remained entrapped within the ice matrix. Eicken (1992) has suggested that exclusion of larger organisms may occur when brine volume is low. This process may exclude krill and other large grazers, which are frequently found within late-season decomposing ice, but we have little evidence to suggest sea- sonal exclusion of the microheterotrophic consumers of the ice assemblage (Figs. $6 \& 7$ ).

In terms of the overall results of the AMERIEZ ice community studies, it may be significant to recognize that all samples have been collected from the marginal ice zone in relatively low-latitude ice and in outflow regions from the Weddell Sea. This region may have a more favorable light and temperature regime than in other regions, particularly those from higher latitudes. This history may be reflected in biological characteristics of young ice that must have formed locally, but it would be difficult to determine the history of older floes which may have been advected into the region as part of the Weddell gyre circulation.

Finally, there has been considerable concern about the reduction in atmospheric ozone and the corresponding increase in UVB radiation at the sea surface (Coley et al. 1992). Much of the attention has been focused on assessing reduction in planktonic production and assessing the potential for species changes within the plankton assemblage. It should be obvious, however, that sea ice organisms, particularly those in the surface layer assemblages (see Garrison \& Buck 1991) could be markedly affected by increased UV exposure. This would be particularly true for organisms or their resting stages which overwinter in sea ice and are present during the seasonal ozone minimum.

Acknowledgements. This study was supported by an NSF grant to D.L.G. (DPP88-15799, DPP91-17794). Data analysis was completed while D.L.G. was a Visiting Researcher at the National Institute of Polar Research of Japan, and we acknowledge this support. We thank the Captain, crew and technicians of the 'Polar Duke' for their support of our work during the AMERIEZ 88 cruise. We also thank Dave Karl and Georgia Tien for advice about ATP measurements. We thank 
Neal Sullivan for loaning us his ATP photometer for the analysis. We also thank Kurt Buck, M. Spindler and Rolf Gradinger for their careful reading of the manuscript and helpful comments

\section{LITERATURE CITED}

Ackley, S. F., Buck, K. R., Taguchi, S. (1979). Standing crop of algae in the sea ice of the Weddell Sea region. Deep Sea Res. 26A: 269-281

Arrigo, K. R., Sullivan, C. W., Kremer, J. N. (1991). A biooptical model of sea ice in McMurdo Sound, Antarctica. J. geophys. Res. 96: 10581-10592

Assur, A. (1958). Composition of sea ice and its tensil strength. In: Arctic sea ice. NAS, NRC, Washington, DC, Publ. 598: $106-138$

Bartsch, A. (1989). Sea ice algae of the Weddell Sea (Antarctica): species composition, biomass, and ecophysiology of selected species. Ber. Polarforsch. 63: 1-110

Beers, J. R., Stewart, G. L. (1970). Numerical abundance and estimated biomass of microzooplankton. In: Strickland, J. D. H. (ed.) The ecology of the plankton off La Jolla, Caiifornia in the period April through September, 1967. Bull. Scripps Instn Oceanogr. 17: 67-87

Booth, B. C. (1987). The use of autofluorescence for analyzing oceanic phytoplankton communities. Bot. Mar. 30: $101-108$

Bratback, G., Dundas, I. (1984). Bacterial dry matter content and biomass estimations. Appl. environ. Microbiol. 48: $755-757$

Buck, K. R., Bolt, P., Garrison, D. L. (1989). Phagotrophy and fecal pellet production by an athecate dinoflagellate in Antarctic sea ice. Mar. Ecol. Prog. Ser. 60:75-84

Buck, K. R., Bolt, P. A., Bentham, W. N., Garrison, D. L. (1992). Dinoflagellate cysts associated with Antarctic sea ice. J. Phycol. 28: 15-18

Bunt, J. S., Lee, C. C. (1970). Seasonal primary production in Antarctic sea ice at McMurdo Sound in 1967. J. mar. Res. 28: $304-320$

Clarke, D. B., Ackley, S. F. (1984). Sea ice structure and biological activity in the Antarctic marginal ice zone. J. geophys. Res. 89: 2087-2095

Close, A. R. (1989). The chemical composition of Antarctic pack ice communities in early austral winter. M.Sc. thesis, Univ. California, Santa Cruz

Coleman, A. W. (1980). Enhanced detection of bacteria in natural environments by fluorochrome staining of DNA. Limnol. Oceanogr. 25: 948-951

Coley, T., Smith, R. C., Prezelin, B. B., Baker, K. S., Bidigare, R. R, Boucher, N. P., Karentz, D., MacIntyre, S., Matlick, H. A., Menzies, D., Ondrusek, M., Wan, Z., Waters, K. J. (1992). Ozone depletion: ultraviolet radiation and phytoplankton biology in Antarctic waters. Science 255: 952-959

Cota, G. F., Smith, W. O. Jr, Nelson, D. M. Muench, R. D., Gordon, L. I. (1992). Nutrient and phytoplankton distributions, primary productivity and nitrogen uptake in the Weddell-Scotia Sea marginal ice zone in winter. J. mar. Res. 50: 155-181

Daly, K. L. (1990). Overwintering development, growth and feeding of larval Euphausia superba in the Antarctic marginal ice zone. Limnol. Oceanogr. 35: 1564-1576

Daly, K. L., Macaulay, M. C. (1991). Influence of physical and biological mesoscale dynamics of the seasonal distribution and behavior of Euphausia superba in the Antarctic marginal ice zone. Mar. Ecol. Prog. Ser. 79: 37-66
Dieckmann, G., Sullivan, C. W., Garrison, D. L. (1990). Seasonal standing crop of ice algae in pack ice of the Weddell Sea. EOS 71: 79

Dieckmann, G. S., Spindler, M., Lange, M. A., Ackley, S. F., Eicken, H. (1991). Antarctic sea ice: a habitat for the foraminiferan Neoglobquadrina pachyderma. J. foram. Res. 21: 181-194

Eicken, H. (1992). The role of sea ice in structuring Antarctic ecosystems. Polar Biol. 12: 3-13

Eicken, H., Lange, M. A. (1989). Development and properties of sea ice in the coastal regime of the southeastern Weddell Sea. J. geophys. Res. 94: 8193-8206

Eppley, R. W., Reid, F. M. H., Strickland, J. D. H. (1970). Estimates of phytoplankton crop size, growth rate, and primary production. In: Strickland, J. D. H. (ed.) The ecology of the phytoplankton off La Jolla, California in the period April through September, 1967. Bull. Scripps Instn Oceanogr. 17: 33-42

Frankenstein, G., Garner, R. (1967). Equations for determining the brine volume of sea ice from -0.5 to $-22.9^{\circ} \mathrm{C}$. J. Glaciol. 6: 943-944

Garrison, D. L. (1991). Antarctic sea ice biota. Am. Zool. 31: $17-33$

Garrison, D. L., Ackley, S. F., Buck, K. R. (1983). A physical mechanism for establishing algal populations in frazil ice. Nature 306: 363-365

Garrison, D. L., Buck, K. R. (1986). Organism losses during ice melting: a serious bias in sea ice community studies. Polar Biol. 6: 237-239

Garrison, D. L., Buck, K. R. (1989). The biota of Antarctic Pack ice in the Weddell Sea and Antarctic peninsula regions. Polar Biol. 10: 211-219

Garrison, D. L., Buck, K. R. (1991). Surface-layer sea ice assemblages in Antarctic pack ice during the austral spring: environmental conditions, primary production and community structure. Mar. Ecol. Prog. Ser. 75: 161-172

Garrison, D. L., Buck, K. R., Fryxell, G. A. (1987). Algal assemblages in Antarctic Pack ice and in ice-edge plankton. J. Phycol. 23: 564-572

Garrison, D. L., Buck, K. R., Gowing, M. M. (1993). Winter plankton assemblage in the ice edge zone of the Weddell and Scotia Seas: composition, biomass and spatial distributions. Deep Sea Res. 40: 311-338

Garrison, D. L., Close, A. R., Gordon, L. I. (1990). Nutrient concentrations in Antarctic pack ice during the austral winter. In: Ackley, S. F., Weeks, W. F. (eds.) Sea ice properties and processes. Proceedings of W. F. Weeks Sea Ice Symposium. CRREL, Monograph 90-1, p. 35-40

Garrison, D. L., Close, A. R., Reimntz, E. (1989). Algae concentrated by frazil ice: evidence from laboratory and field measurements. Antarct. Sci. 1: 313-316

Garrison, D. L., Sullivan, C. W., Ackley, S. F. (1986). Sea ice microbial communities in Antarctica. BioSci. 36: 243-250

Garrison, D. L., Watanabe, K. (1991). Microbial assemblages in Antarctic sea ice: a comparison of the pack and landfast ice habitats. In: Aota, M., Shirasawa, K. (eds.) Proceedings of Sixth International Symposium on Okhotsk Sea and Sea Ice, February 3-5. Okhotsk Sea and Cold Ocean Research Association, Mombetsu, Hokkaido, p. $80-88$

Gold, K. (1976). Methods for preserving Tintinnida. In: Steedman, H. F. (ed.) Zooplankton fixation and preservation. UNESCO, Paris, p. 236-239

Gow, A. J., Ackley, S., Buck, K. R., Golden, K. M. (1987). Physical and structural characteristics of Weddell Sea pack ice. CRREL Report 87-14: 1-70

Grossi, S. M., Kottmeier, S. T., Moe, R. L., Taylor, G. T., Sulli- 
van, C. W. (1987). Sea ice microbial communities. VI. Growth and primary productivity in bottom ice under graded snow cover. Mar. Ecol. Prog. Ser. 35: 153-164

Holm-Hansen, O., Booth, C. R. (1966): The measurement of adenosine triphosphate in the ocean and its ecological significance. Limnol. Oceanogr. 11:510-519

Holm-Hansen, O., Karl, D. (1978). Biomass and adenylate energy charge determination in microbial cell extracts and environmental samples. Meth. Enzymol. 57: 73-85

Horner, R. A., Syvertsen, E. E., Thomas, D. P., Lange, C. (1988). Proposed terminology and reporting units for sea ice algal assemblages. Polar Biol. 8: 249-253

Hoshiai, T. (1981). Proliferation of ice algae in the Syowa station area, Antarctica. Mem. natn. Inst. polar Res., Ser. E, Biology 34: 1-12

Irwin, B. D. (1990). Primary production of ice algae on a seasonally ice covered, continental shelf. Polar Biol. 10: $247-254$

Kottmeier, S. T., Sullivan, C. W. (1987). Late winter primary production and bacterial production in sea ice and seawater west of the Antarctic Peninsula. Mar. Ecol. Prog. Ser. 36: $287-298$

Kottmeier, S. T., Sullivan, C. W. (1988). Sea ice microbial communities (SIMCO). 9. Effects of temperature and salinity on rates of metabolism and growth of autotrophs and heterotrophs. Polar Biol. 8: 293-304

Kottmeier, S. T., Sullivan, C. W. (1990). Bacterial biomass and production in pack ice of Antarctic marginal ice edge zones. Deep Sea Res. 37: 1311-1330

Lange, M. A. (1988). Basic properties of Antarctic sea ice as revealed by textural analysis of ice cores. Ann. Glaciol. 10: 95-101

Lange, M. A., Schlosser, P., Ackley, S. F., Wadhams, P., Dieckmann, G. S. (1990). ${ }^{18} \mathrm{O}$ concentrations in sea ice of the Weddell Sea, Antarctica. J. Glaciol. 36: 315-323

Lee, S., Fuhrman, J. A. (1987). Relationships between biovolume and biomass of naturally derived marine bacterioplankton. Appl. environ. Microbiol. 53: 1298-1030

Lizotte, M. P., Sullivan, C. W. (1991). Photosynthesis-irradiance relationships in microalgae associated with Antarctic pack ice: evidence for in situ activity. Mar. Ecol. Prog. Ser. 71: $175-184$

Meguro, H., Ito, K., Fukushima, H. (1967). Ice flora (bottom type): a mechanism of primary production in polar seas and the growth of diatoms in sea ice. Arctic 20:114-133

Mitchell, J. G., Silver, M. W. (1982). Modern archaeomonads indicate sea-ice environments. Nature 296: 437-439

Muench, R. T., Gunn, J. T., Husby, D. M. (1990). The WeddellScotia Confluence in mid-winter. J. geophys. Res. 95: 365-371

Palmisano, A. C., SooHoo, J. B., Sullivan, C. W. (1987). Effects of four environmental variables on photosyntheis-irradiance relationships in Antarctic sea-ice microalgae. Mar. Biol. 94: 299-306

Palmisano, A. C., Sullivan, C. W. (1983). Sea ice microbial communities (SIMCO). 1. Distribution, abundance, and primary productivity of ice microalgae in McMurdo Sound, Antarctic in 1980. Polar Biol. 2: 171-177

Parsons, T. R., Maita, Y., Lalli, C. M. (1984). A manual of chemical and biological methods for seawater analysis. Pergamon Press, Oxford

Putt, M., Stoecker, D. K. (1989). An experimentally determined carbon: volume ratio for marine 'oligotrichous' ciliates from estuaries and coastal waters. Limnol. Oceanogr. 34: $1097-1103$

Spindler, M., Dieckmann, G. S. (1986). Distribution and abundance of the planktic foraminifer Neogloboquadrina pachyderma in sea ice of the Weddell Sea (Antarctica). Polar Biol. 5: 185-191

Spindler, M., Dieckmann, G. S., Lange, M. A. (1990). Seasonal and geographic variations in sea ice community structure of the Weddell Sea, Antarctica. In: Kerry, K. R., Hempel, G. (eds.) Antarctic ecosystems, ecological change and conservation. Springer-Verlag, Berlin, p. 129-135

Stoecker, D. K. Buck, K. R., Putt, M (1990). A flagellate- and ciliate-dominated microbial community in the land-fast ice. (1990). Antarct. J. U.S. 25: 197-199

Stringer, W. J., Barnett, D. G., Godin, R. H. (1984). Handbook for sea ice analysis and forecasting. NASC, U.S. Navy CR84-03: $1-324$

Taljaard, J. J., van Loon, H., Crutcher, H. L. Jenne, R. L. (1969). Climate of the upper air, Southern Hemisphere. Vol. 1. Temperatures, dew points, and heights at selected pressure levels. U.S. Dept Commerce, Washington, DC

Zwally, H. J., Comiso, J. C., Parkinson, C. L., Campbell, W. J., Carsey, F. D., Gloersen, P. (1983). Antarctic Sea Ice 1973-1976: satellite passive-microwave observations. NASA, Washington, DC, NASA Spec. Publ. 459

Manuscript first received: June 29, 1992

Revised version accepted: February 3, 1993 